\title{
PENGELOLAAN BANK SAMPAH DALAM MENDUKUNG GO GREEN CONCEPT DI DESA ULAKAN TAPAKIS KABUPATEN PADANG PARIAMAN
}

\author{
Bustanul Arifin*, Taufiq Ihsan, Olly Norita Tetra, Nofrita, Fadjar Goembira \\ dan Frenadin Adegustara \\ Pusat Studi Lingkungan Hidup Universitas Andalas Padang \\ * Email: ba_arifin@yahoo.co.id
}

\begin{abstract}
ABSTRAK
Pengelolaan bank sampah pada masyarakat Nagari Ulakan perlu dilakukan sebagai solusi dalam pengurangan sampah, pengelolaan dan pengolahan sampah. Meningkatnya pertumbuhan wisata akan meningkatkan jumlah sampah di Nagari Ulakan. Bukan hanya material sampahnya yang menjadi masalah, akan tetapi pembuangan, pengelolaan, dan pengolahan sampah terkadang menjadi masalah serius yang perlu ditangani dengan baik di Nagari ini. Tujuan kegiatan pengabdian masyarakat ini adalah dengan keberadaan bank sampah bisa memberikan solusi terbaik dalam pencapaian target pengurangan sampah di Nagari Ulakan Kecamatan Tapakis Kabupaten Padang Pariaman. Pengelolaan bank sampah dilakukan untuk mendukung Go Green Concept melalui penyuluhan mengenai sosialisasi bank sampah, pengertian, kegunaan, dan tahap-tahap proses persiapan pembentukan bank sampah. Pada penyuluhan ini juga diperkenalkan jenis-jenis sampah, proses pemilahan sampah, contoh-contoh pengolahan sampah kertas dan plastik. Kegiatan dilanjutkan dengan pendampingan dalam tahap pembentukan manajemen bank sampah dan operasional bank sampah. Hasil dari kegiatan ini adalah berkurangnya jumlah sampah serta terbentuknya bank sampah di Nagari Ulakan dan meningkatnya kepedulian masyarakat akan pengelolaan sampah.
\end{abstract}

Kata Kunci : bank sampah, Ulakan, pengelolaan sampah, dan pengolahan sampah

\section{Waste Bank Management in Supporting Go Green Concept in Nagari Ulakan Tapakis Kabupaten Padang Pariaman}

\begin{abstract}
Waste bank management in the Nagari Ulakan community needs to be done as a solution in waste reduction, waste management and processing. The increase in tourists will increase the amount of waste in Nagari Ulakan. the problem is not the amount of waste but the disposal, management and processing of waste which is a serious problem and must be handled properly in Nagari. The purpose of this community service activity is the existence of a waste bank can provide the best solution in achieving the target of waste reduction in Nagari Ulakan, Kecamatan Tapakis, Kabupaten Padang Pariaman. The waste bank management is carried out to support the Go Green Concept through counselling on the socialization of the waste bank, the usefulness, and the stages of the preparation process for forming a waste bank. In this counselling introduced types of waste, waste sorting processes, examples of paper and plastic waste processing. The activity was followed by mentioning at the stage of forming a waste bank management and waste bank operations. The results of this activity are the reduction of waste and the formation of a waste bank in Nagari Ulakan and increasing public awareness of waste management.
\end{abstract}

Keywords : waste bank, Ulakan, waste bank management and waste processing 


\section{PENDAHULUAN}

Kenagarian Ulakan berada di Kecamatan Tapakis yang merupakan salah satu kecamatan dari 15 Kecamatan di Kabupaten Padang Pariaman dengan luas $47000 \mathrm{Ha}$ yang terdiri dari 5 Korong. Kenagarian Ulakan terdiri dari 2347 laki laki dan 2212 perempuan dan sekitar 497 jiwa penduduknya pengangguran dan mereka lebih dominan sebagai pedagang dan buruh tani. Daerah ini merupakan daerah wisata religi yang dikenal dengan Basapa, dimana pada waktu tertentu ramai dikunjungi oleh wisatawan baik dalam negeri maupun dari luar negeri. Kondisi geografis yang merupakan sebagai jalur alternatif menuju bandara menjadikan daerah ini menjadi daerah perlintasan (https://sandiulakan.padangpariamankab.go.id/first/artikel/32)

Permasalahan sampah saat ini tidak hanya menjadi tanggung jawab pemerintah akan tetapi harus menjadi tanggung jawab seluruh lapisan masyarakat di Indonesia. Berbagai upaya masyarakat dalam mengelola dan pengolahan sampah telah banyak dipelopori oleh ahli lingkungan, tokoh-tokoh masyarakat/lembaga-lembaga yang peduli lingkungan. Pengelolaan sampah saat ini diawali melalui $3 \mathrm{R}$ yaitu reduce, reuse dan recycle atau pengurangan, penggunaan kembali dan daur ulang sampah (Asisten Deputi Pengelolaan Sampah Deputi Pengelolaan B3, 2012). Kegiatan 3R ini masih menghadapi kendala utama dalam pelaksanaannya yaitu rendahnya partisipiasi dan kesadaran masyarakat dalam memilah sampah, hal ini bisa juga dikarenakan belum adanya pengetahuan masyarakat akan jenis-jenis sampah seperti sampah organic, anorganik dan limbah B3. (Ahmad, 2012)

Sebagai solusi dalam mengatasi masalah tersebut adalah melalui pengembangan Bank Sampah, dimana kegiatan ini bersifat social engineering yang mengajarkan dan memperkenalkan kepada masyarakat untuk memilah sampah serta menumbuhkan kesadaran masyarakat akan pengolahan sampah secara baik dan cerdas, yang pada akhirnya akan mengurangi sampah yang diangkut ke tempat penampungan akhir (TPA). Pembangunan bank sampah ini harus menjadi momentum awal dalam membina kesadaran masyarakat secara universal untuk memulai dalam memilah, mendaur-ulang, dan memanfaatkan sampah, karena tanpa disadari sampah sebenarnya mempunyai nilai jual yang cukup baik, sehingga pengelolaan sampah yang berwawasan lingkungan dapat dijadikan sebagai budaya baru di Indonesia.

Pengertian pengelolaan sampah adalah semua kegiatan/aktivitas yang dilakukan untuk menangani sampah mulai dari sejak ditimbulkan sampai dengan pembuangan akhir dari sampah tersebut. Adapun kegiatan pengelolaan sampah meliputi dalam hal pengendalian timbulan sampah, pengumpulan sampah, pengangkutan, pengolahan dan pembuangan akhir (Sejati, 2004). Pengelolaan sampah bisa dilakukan dengan memanfaatkan limbah menjadi produk yang bernilai ekonomi tinggi seperti pemanfaatan sampah kertas menjadi produk kerajinan yang unik dan artistic. (Tetra, ON dkk, 2018 dan 2019) Menurut Aryenti (2011), Bank Sampah merupakan tempat menabung yang berupa sampah yang telah terpilah menurut jenis sampahnya. Cara kerja Bank Sampah ini pada umumnya hampir sama dengan bank, dimana terdiri dari nasabah, adanya pencatatan pembukuan dan yang terpenting manajemen pengelolaannya. Apabila dalam bank yang sebenarnya yang disetorkan nasabah adalah uang, maka dalam Bank Sampah yang disetorkan adalah sampah yang mempunyai nilai ekonomis. Bank sampah yang dibentuk sebaiknya dikelola oleh orang 
yang kreatif dan inovatif, dan memiliki jiwa kewirausahaan, sehingga dapat meningkatkan pendapatan masyarakat. Sistem kerja Bank Sampah di Nagari Ulakan ini dilakukan berbasis rumah tangga, dengan memberikan hadiah kepada mereka yang berhasil memilah dan menyetorkan sejumlah sampah sesuai dengan ketentuan yang berlaku.

Di Nagari Ulakan sendiri belum dimulai program bersih lingkungan dengan mengelola sampah dengan bijaksana. Masyarakat masih belum mengetahui cara pemilahan sampah dan cara mendaur ulang sebagai antisipasi pengurangan jumlah sampah. Di nagari ini juga belum ditemukan adanya bank sampah, pengetahuan masyarakat yang minim dan kurangnya informasi membuat kondisi kesadaran dan tanggung jawab masyarakat terhadap pengendalian sampah masih kurang. Apalagi jarak pemukiman dengan tempat penampungan sampah sangat jauh, sedangkan pengambilan sampah dari pemerintah daerah belum sampai ke daerah kabupaten, menyebabkan masyarakat hanya mengolah sampah seadanya (Tim Studi EHRA, 2016)

Tujuan kegiatan pengabdian ini adalah memperkenalkan bank sampah dan pendirian Bank Sampah di Nagari Ulakan Kabupaten Padang Pariaman. Kegiatan ini diharapkan dapat membantu menangani pengolahan sampah di Ulakan dan dapat menyadarkan masyarakat akan lingkungan yang sehat, rapi, dan bersih sehingga terciptanya Go Green Concept. Bank Sampah yang akan didirikan bertujuan untuk mengubah sampah menjadi sesuatu yang lebih berguna dalam masyarakat, misalnya untuk kerajinan (sampah plastik dan kertas) dan pupuk yang memiliki nilai ekonomis (sampah basah/sampah dapur).

\section{METODE}

Metode pelaksanaan pengabdian masyarakat ini adalah :

\section{Tahap Penentuan Lokasi Kegiatan}

Pada tahap ini dilakukan koordinasi dan kunjungan ke kantor Walinagari Ulakan untuk menentukan tempat (lokasi) kegiatan, topik dan waktu pelatihan. Dari hasil diskusi di sepakati bahwa kegiatan pelatihan dan penyuluhan dilakukan pada tanggal 24 Oktober 2019 pada hari Kamis di Kantor Walinagari Ulakan Kecamatan Ulakan Tapakis Kabupaten Padang Pariaman. Kegiatan dimulai pada jam $9.00-$ 16.00 WIB yang rencana akan dihadiri oleh jumlah peserta \pm 35 orang.

Sasaran peserta kegiatan ini adalah anggota PKK, kelompok organisasi pemuda, dan dasa wisma.

\section{Tahap Pelaksanaan Kegiatan Penyuluhan}

Tahap ini dilakukan untuk meningkatkan pemahaman masyarakat akan jenis-jenis sampah, pemilahan dan pentingnya bank sampah dalam pengelolaan sampah berbasis masyarakat. Kegiatan penyuluhan ditentukan berdasarkan kesepakatan tempat dan waktu yang telah disepakati sebelumnya.

Kegiatan penyuluhan ini di lakukan secara langsung dengan memberikan materi berupa sosialisasi tentang jenis-jenis sampah, proses pemilahan sampah dan dilanjutkan dengan penyuluhan tentang pengenalan bank sampah, contoh kasus dan 
sharing berupa diskusi dan tanya jawab. Kegiatan ini dibantu dengan penyampaian dengan power point, berupa gambar, data dan fakta, dimana penyajian dilakukan selama 90 menit dan dilanjutkan dengan diskusi selama 90 menit.

\section{Melakukan Monitoring, Pendampingan dan Evaluasi}

Kegiatan ini dilakukan setelah kegiatan penyuluhan, dengan memonitoring tahap awal yang harus disiapkan dalam pembentukan bank sampah seperti pembentukan pengurus dan dilakukan pendampingan mulai dari persiapan penentuan tempat bank, kepengurusan/manajemen pengelola, staf pengelola, pembuatan buku bank, dan pengepul yang akan bekerja sama dalam penerima sampah.

\section{HASIL DAN PEMBAHASAN}

Kegiatan pengabdian masyarakat diawali dengan penetapan lokasi kegiatan yang diadakan dan berdasarkan kesepakatan dengan Walinagari Ulakan bahwa kegiatan dilakukan di Kantor Walinagari Ulakan Kecamatan Ulakan Tapakis Kabupaten Padang Pariaman yang dihadiri \pm 40 peserta yang merupakan perwakilan dari kelompok PKK, kelompok Dasa wisma dan kelompok pemuda nagari Ulakan.

Kegiatan penyuluhan diawali dengan sosialisasi tentang definisi sampah, jenis-jenis sampah dan proses pemilahan sampah yang merupakan dasar pengetahuan untuk pengenalan bank sampah. Topik ini diberikan dengan tujuan memberikan pemahaman masyarakat akan pentingnya bank sampah dan pengelolaan sampah berbasis masyarakat. Proses pelaksanaan kegiatan penyuluhan pengenalan bank sampah:

\section{Kegiatan sosialisasi kepada masyarakat}

a. Kegiatan sosialisasi dan penyuluhan jenis-jenis sampah dan bahaya sampah terhadap lingkungan dan kesehatan. Pada tahap ini telah dilakukan sosialisasi gagasan kepada masyarakat dan tokoh masyarakat tentang bank sampah, pengelolaan sampah berbasis masyarakat dan bahaya sampah terhadap kesehatan dan lingkungan.

Bank Sampah memiliki beberapa manfaat bagi manusia dan lingkungan hidup, seperti membuat lingkungan lebih bersih, menyadarkan masyarakat akan pentingnya kebersihan, dan membuat sampah menjadi barang ekonomis. (Kuncoro Sejati. 2009) Manfaat lain Bank Sampah untuk masyarakat adalah dapat menambah penghasilan masyarakat karena saat mereka menukarkan sampah mereka, maka mereka akan mendapatkan imbalan berupa uang, dimana uang ini dikumpulkan dalam rekening tabungan yang mereka miliki dan selanjutnya bisa dimanfaatkan seperti untuk membayar iuran listrik, uang sekolah anak ataupun modal usaha. (Aryeti, 2011).

Proses pada tahapan kegiatan penyuluhan ini dapat dilihat pada foto-foto kegiatan di Gambar 1. 

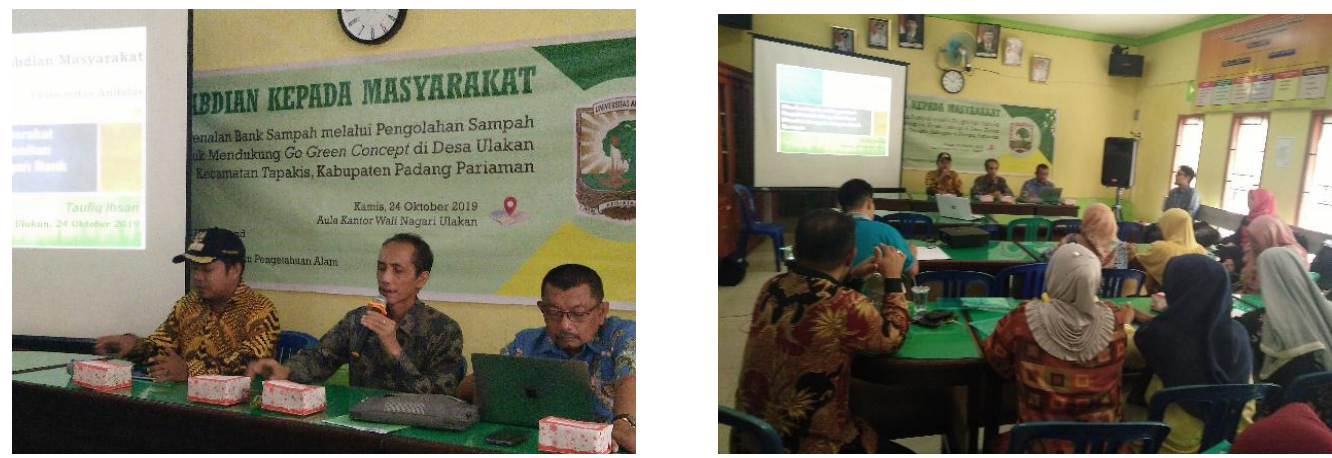

Gambar 1. Kegiatan Penyuluhan Sosialisasi tentang Sampah Mulai Dari Jenis-Jenis Sampah, Pemilahan dan Dampak Sampah Terhadap Kesehatan dan Lingkungan

b. Kegiatan penyuluhan pengenalan bank sampah dan pembentukan tim pengelola bank sampah

Pada tahap ini di berikan pengetahuan kepada peserta kegiatan tentang bank sampah dan proses pendirian bank sampah (Gambar 2). Dalam proses pendirian bank sampah maka haruslah ditetapkan tim pengelola bank sampah atau pengurus, Kepengurusan ini harus disepakati dan di sahkan dalam bentuk surat keputusan yang dikeluarkan oleh pimpinan setempat yaitu Walinagari Ulakan. Tim pengelola bank sampah ini dapat terdiri dari pelindung biasanya oleh Kepala Dusun/Jorong atau Korong. Ketua pelaksana biasanya dipegang oleh penggagas, sekretaris, bendahara, seksi penerimaan sampah, seksi pemilahan, seksi humas dan seksi-seksi lain yang diperlukan sesuai kesepakatan bersama pada saat pelatihan.
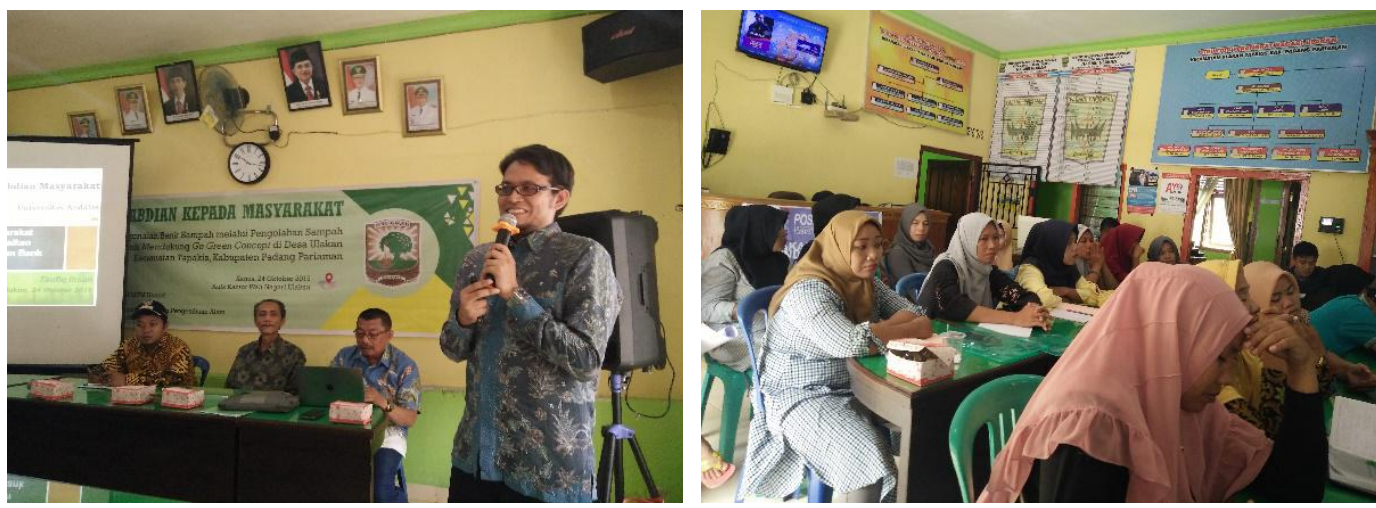

Gambar 2. Kegiatan Penyuluhan Pengenalan Bank Sampah dan Proses Pendirian Bank Sampah

\section{c. Kegiatan Kerjasama Dengan Pengepul Sampah}

Pihak-pihak yang bersedia membeli sampah adalah orang-orang yang mengumpulkan barang-barang rongsokan (pengepul) berupa sampah-sampah 
yang dapat di daur ulang atau anggota bank sampah yang bisa melakukan pengolahan sampah. Dalam bekerja sama dengan pengepul haruslah ditetapkan harga per kilogram untuk masing-masing jenis sampah dan waktu untuk pengambilannya. Pada kegiatan ini ada 3 nama pengepul yang akan bekerja sama dengan bank sampah Ulakan ini.

\section{Melakukan Monitoring Dan Evaluasi Kegiatan}

Monitoring dan evaluasi dilakukan setelah kegiatan penyuluhan dan sosialisasi. Pada kegiatan ini peserta didampingi dalam proses pembentukan kepengurusan, pemberian nama bank sampah, sosialisasi dan proses menabung di bank sampah sampai penentuan tempat/lokasi bank sampah. Pemberian nama bank sampah disepakati adalah bank sampah Ulakan.

Adapun kegiatan ini dapat dilihat pada Gambar 3. Sedangkan calon pengurus dan rencana lokasi bank sampah Ulakan dapat dilihat pada Gambar 4.
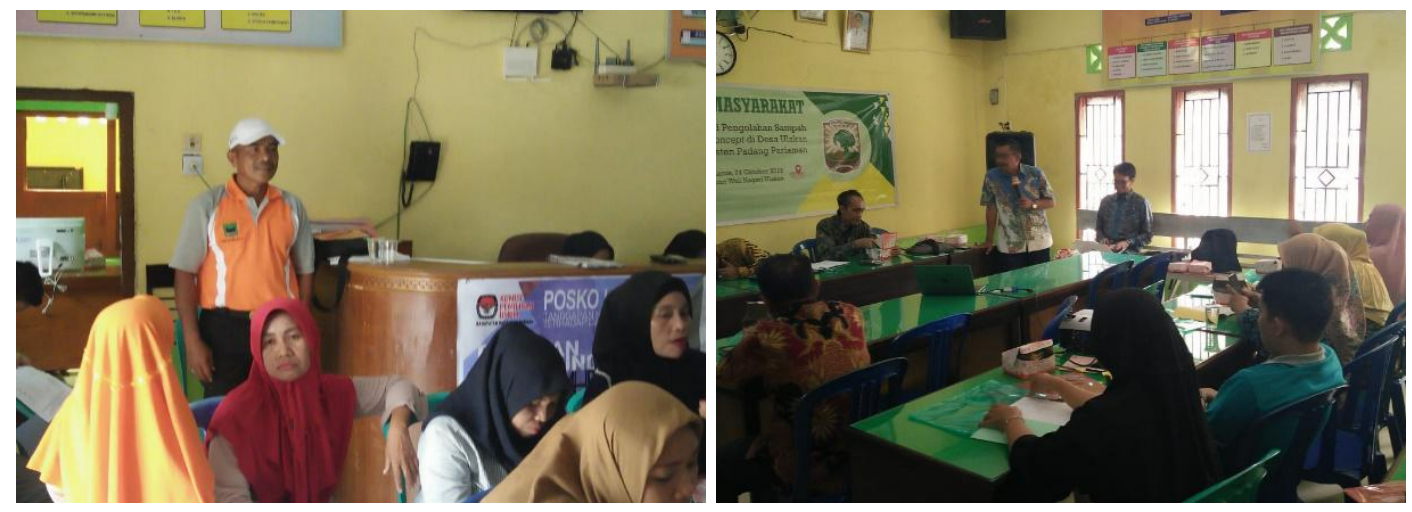

Gambar 3. Proses Penetapan Kepengurusan Bank Sampah Ulakan
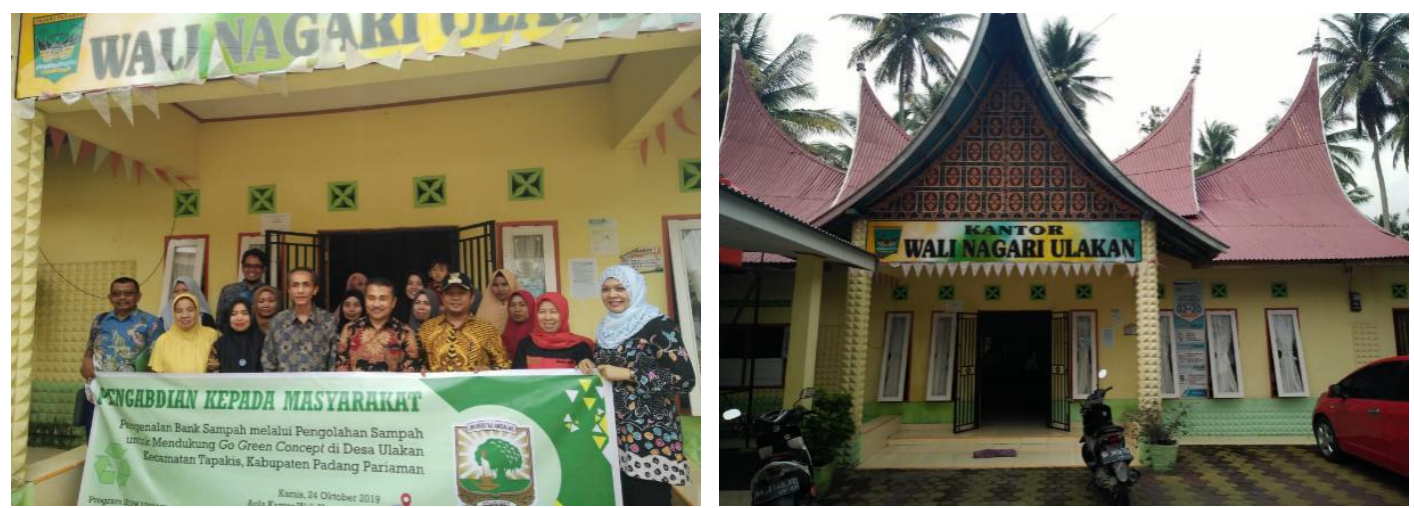

Gambar 4. Foto Bersama Calon Pengurus Bank Sampah Ulakan dan Rencana Tempat Pendirian Bank Sampah Dekat Kantor Walinagari Ulakan.

Pada Nagari Ulakan ini, setelah diberikan penyuluhan tentang pengenalan bank sampah dan proses pembentukan bank sampah, maka di sepakati untuk memulai 
pembuatan bank sampah dengan diawali yaitu :

1. Penentuan tempat/lokasi kantor bank sampah

2. Pembentukan SK dari Walinagari untuk pengurusan bank sampah (personel yang terlibat dalam penyelenggaraan bank sampah)

3. Sosialisasi kepada masyarakat Ulakan akan adanya bank sampah dan mengikutsertakan masyarakat untuk jalannya bank sampah

Adapun alur kerja pembentukan bank sampah yang dilaksanakan di Ulakan adalah

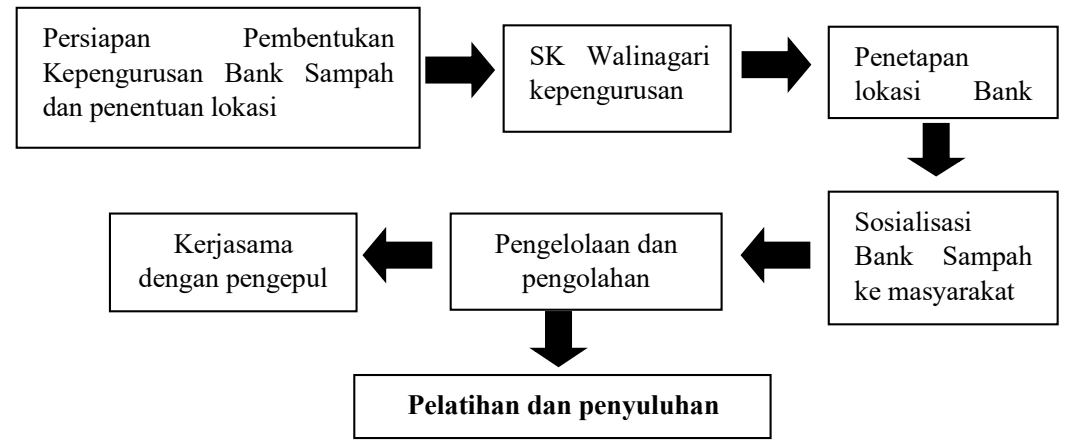

Gambar 5. Skema Alur Kerja Pembentukan Bank Sampah di Ulakan Tapakis

Pada kegiatan penyuluhan ditemukan kesulitan dimana dalam penggunaan bahasa Indonesia yang sulit dipahami oleh peserta, sehingga dalam penyuluhan digunakan bahasa daerah (Minang) untuk memudahkan komunikasi kepada peserta. Kendala lainnya adalah belum adanya pemahaman yang sama antara masyarakat, tokoh-tokoh masyarakat, dan kelompok masyarakat terutama pada tingkat nagari ini terkait dengan manfaat dari Bank Sampah. Dimana ditemukan bahwa masih adanya pemahaman bahwa Bank Sampah itu sama dengan pekerjaan pemulung dan pengepul sampah, yang merupakan pekerjaan hina atau rendahan, dan bahwa pemahaman bahwa kegiatan apapun yang berhubungan dengan sampah pasti bau dan ini termasuk kegiatan Bank Sampah.(Tetra O.N, 2020) Kendala seperti hal tersebut perlu ditangani dengan terus menerus melakukan sosialisasi dan pembuktian bahwa Bank Sampah akan dapat memberikan manfaat bagi masyarakat Ulakan, tidak hanya dari segi kesehatan dan lingkungan tetapi juga lebih ekonomis.

Berdasarkan hasil kegiatan ini diketahui bahwa jumlah sampah dan pengelolaan sampah dipengaruhi oleh kepedulian dan keikutsertaan anggota keluarga suatu kelompok masyarakat. Jumlah anggota dapat memengaruhi keikutsertaan masyarakat dalam menabung di bank sampah karena jumlah anggota keluarga memiliki pengaruh terhadap kuantitas sampah yang dihasilkan. Tidak mengherankan jumlah anggota keluarga yang besar ditemukan menghasilkan secara total sampah yang lebih banyak daripada keluarga kecil. (Selomo, 2016) Tingkat pengetahuan masyarakat akan jenis-jenis sampah dan bagaimana pengelolaannya terutama sampah kertas dan plastic merupakan hal yang mendasar dan penting dalam pengembangan dan pengelolaan Bank sampah terutama dalam hal produk daur ulang. Melalui edukasi berupa penyuluhan dan pelatihan kepada masyarakat diharapkan dapat mengubah kebiasaan 
masyarakat dalam mengelola sampah. Dalam hal ini kehadiran bank sampah merupakan salah satu alternative dalam mengatasi permasalahan sampah baik di perkotaan atau pun Kabupaten. Adanya pengembangan bank sampah akan lebih maju apabila adanya dukungan dari pemerintah daerah setempat dan pihak masyarakat ataupun tokoh masyarakat yang berpengaruh di daerah tersebut. Pengaruh pihak pemerintah daerah setempat sangat diperlukan dalam mendukung kelancaran kegiatan serta peran pihak perusahaan/pengusaha lokal untuk meningkatkan nilai ekonomis dari pengolahan sampah di daerah. (Asteria dan Heruman, 2016) Dampak sosial keberadaan Bank Sampah dapat dipelajari dari Bank Sampah Semali Berseri di Magelang dimana adanya bank sampah dianalisis berdasarkan jumlah tenaga kerja yang terserap, persepsi warga sekitar, dan ada tidaknya perubahan perilaku dalam penanganan sampah rumah tangga.(Sudati S, Whinarko J. 2017)

Kegiatan ini sangat mendapatkan dukungan dari aparat daerah Nagari Ulakan seperti Walinagari, Kepala Bamus dan LPM setempat dan khususnya masyarakat Nagari Ulakan Kabupaten Padang Pariaman. Kegiatan ini juga sudah dipublikasikan dalam bentuk koran khazanah dan Padang Ekspres untuk 2 kali kegiatan penyuluhan (Gambar 5).
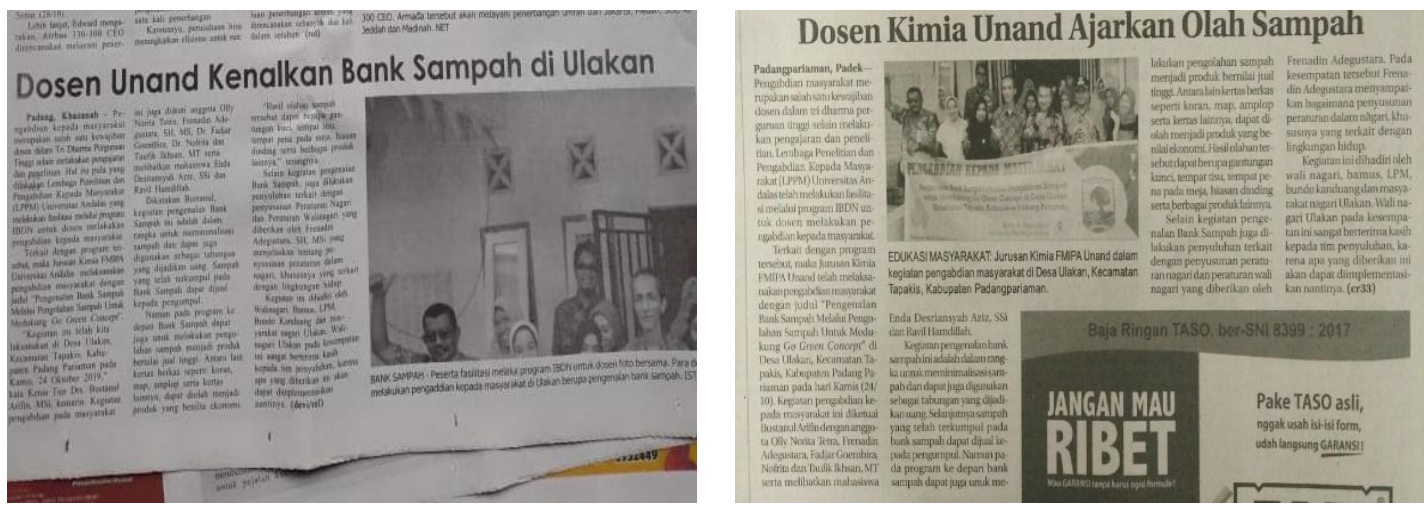

Gambar 5. Publikasi Kegiatan di Koran Khazanah dan Padang Ekspres

\section{KESIMPULAN DAN SARAN}

\section{Kesimpulan}

Kegiatan pengabdian masyarakat di Nagari Ulakan Kecamatan Tapakis Kabupaten Padang Pariaman dengan topik pengenalan bank sampah untuk mendukung Go Green Concept telah dilakukan. Kegiatan diawali dengan penyuluhan dan sosialisasi tentang sampah, proses pemilahan sampah dan pengelolaan serta pengolahan sampah. Kegiatan dilanjutkan dengan proses pendirian bank sampah dengan membentuk kepengurusan dan penentuan lokasi bank sampah serta melakukan kerja sama dengan pengepul. Go Green Concept terlaksana melalui program pengelolaan sampah mandiri melalui Bank Sampah sebagai solusi untuk mengurangi peningkatan volume sampah yang semakin meningkat di Nagari Ulakan. 
Pendirian bank sampah ini selain memberikan dampak positif bagi kesehatan, lingkungan, dan dalam proses pengelolaannya ini bank sampah dapat berkembang sehingga memiliki mekanisme relasi dan jaringan sosial yang bernilai ekonomis khususnya adalah volume sampah yang dibuang ke TPA dapat berkurang.

\section{Saran}

Disarankan untuk pengembangan bank sampah ke depan, diperlukan adanya teknologi pengolahan sampah yang mempunyai nilai ekonomi lebih tinggi. Hal ini bertujuan untuk memotivasi nasabah dengan memberikan harga yang lebih tinggi terhadap sampahnya. Selain itu, diperlukan pula dukungan dan peran serta dari pemerintah daerah dalam menggalakkan program Bank Sampah dan kerja sama dengan pihak swasta seperti melalui Corporate Social Responsibility (CSR), untuk membantu pengembangan Bank Sampah.

\section{UCAPAN TERIMA KASIH}

Kami para pelaksana kegiatan pengabdian masyarakat mengucapkan terima kasih kepada lembaga penelitian dan pengabdian masyarakat atas bantuannya dalam Program Pengabdian Kepada Masyarakat IPTEK Berbasis Dosen dan Masyarakat Dana BOPTN UNIVERSITAS ANDALAS sesuai dengan kontrak Pengabdian Kepada Masyarakat Nomor : T/8/UN.16.17/PM.IbDM/LPPM/2019 Tahun anggaran 2019.

\section{DAFTAR PUSTAKA}

Ahmad, F. 2012. Partisipasi Masyarakat dalam Pengelolaan Sampah Berbasis Komunitas Lokal (Studi Deskriptif Bank Sampah "Poklili", Kota Depok). Skripsi. Universitas Indonesia, Depok.

Asteria, D dan Heruman, H. 2016. Bank sampah sebagai alternatif strategi pengelolaan sampah berbasis masyarakat di Tasikmalaya. Jurnal Manusia Dan Lingkungan, Vol. 23, No.1. 136-141

Aryeti. 2011. Peningkatan peran serta masyarakat melalui gerakan menabung pada bank sampah di Kelurahan Babakan Surabaya, Kiara Condong Bandung. Jurnal Permukiman, Vol. 6. No. 1: 40-46.

Asisten Deputi Pengelolaan Sampah Deputi Pengelolaan B3, Limbah B3 dan Sampah. 2012. Profil Bank Sampah Indonesia. Kementerian Lingkungan Hidup, Jakarta.

Kuncoro Sejati. 2009. Pengelolaan Sampah Terpadu dengan Sistem Node, Sub Point, Center Point. Kanisius, Yogyakarta 
PressKanisius. 2016. Laporan Studi EHRA (Environmental Health Risk Assessment). Tim Studi EHRA. Kota Pariaman.

Selomo, M, Bintara, A, Birawida, Mallongi, A, Muammar. 2016. Bank sampah sebagai salah satu solusi penanganan sampah di Kota Makassar. Jurnal MKMI, Vol. 12 No. 4, 232-240.

Sudati S, Whinarko J. 2017. Manfaat bank sampah bagi masyarakat di Dusun Semali Desa Salam Kanci Kecamatan Bandongan Kabupaten Magelang. (Study Bank Sampah Semali Berseri). Jurnal Riset Ekonomi Pembangunan. Vol 2, No 2. 165-184.

Suwerda, B. 2010. Bank Sampah Buku I. Werda, Yogyakarta.

Tetra O.N, Arifin B, Aziz H, Zulhadjri, Indrawati, Yusuf Y. 2019. Penerapan teknologi paper filigree 3-dimensi berbasis limbah menjadi produk bernilai ekonomi tinggi dalam meningkatkan pendapatan rumah tangga di Talawi Mudik. Warta Pengabdian Andalas. 26 (4a): 187 - 195

Tetra O.N, Arifin B, Alif A, Zulhadjri, Indrawati, Salim M. 2018. Pemberdayaan perempuan melalui teknologi quilling paper sebagai usaha alternatif berbasis lingkungan di Desa Marunggi Kota Pariaman. Warta Pengabdian Andalas. 25 (1): $1-10$

Tetra O.N, Arifin B, Ihsan T, Nofrita, Goembira F, Adegustara F, Andora H. 2020. Dari Kampus Pulang Ke Nagari (Secuil Cinta Untuk Batu Kalang Utara). LPPM Universitas Andalas Padang

Website Resmi Nagari sandi Ulakan, Kecamatan Ulakan Tapakis Kabupaten Padang Pariaman.https://sandiulakan.padangpariamankab.go.id/first/artikel/32. Diakses tanggal 18 Desember 2019. 